\title{
Culture and the Implementation Process of Strategic Decisions in Jordan
}

\author{
Rifat Odetalla Shannak \\ Associate Professor of Management Information Systems \\ Chairman of MIS Department, Faculty of Business, University of Jordan \\ P. O. Box 13357, 11942 Amman, Jordan \\ E-mail: rshannak@ju.edu.jo
}

Bader Yousef Obeidat

Assistant Professor of Business Management

Department of Business Management, Faculty of Business, University of Jordan, Amman, Jordan

E-mail: obeidat_bader@yahoo.com

Raed M. Masadeh

Assistant Professor, Management Information Systems Department

Faculty of Business, University of Jordan, Amman, Jordan

E-mail: r.masadeh@ju.edu.jo

Received: July 28, 2012 Accepted: September 23, 2012 Published: October 1, 2012

doi:10.5296/jmr.v4i4.2160

URL: http://dx.doi.org/10.5296/jmr.v4i4.2160

\begin{abstract}
This paper studies the nature of the implementation process of strategic decisions within three banks in Jordan. To gain a better view of the implementation process, a qualitative research was carried out. Interviews, observations, and documentation research were used in order to collect the primary data of this study. It is believed that culture might have an effect on the way strategic decisions are implemented in organizations. Having reviewed the extant literature, it was found that four factors may be used to explain the nature of this process
\end{abstract}




\section{Macrothink}

Journal of Management Research

ISSN 1941-899X

2012, Vol. 4, No. 4

within the three banks. These factors are the use of an external company, the use of a simulation technique, the use of an incremental approach, and the use of a buffering time period. Finally, the analysis of the data revealed that culture is expected to play an important role in the implementation process and in the way this process is implemented within banks in Jordan.

Keywords: Strategic Decision, Implementation of Strategy, Culture, Hofstede's Model, Cultural Impacts, Arab Culture 


\section{Introduction}

Strategic decisions or rather the strategic decision making process is concerned with strategy formulation, implementation, and evaluation (Nooraie, 2008; Mockler, 2001; Harrison, 1996). Consequently, when adopting a new strategy, careful attention should be paid to both its development and its implementation. Wery and Waco (2004) commented that:

"Strategy formulation, though important, is only the beginning of a process. Without an executable plan - and the resources needed to implement that plan - even the most innovative strategy is merely words on paper." (p. 153)

It has been noted that organisations have difficulties in implementing their strategies (Aaltonen and Ikavalko, 2002). Research has suggested that half of the decisions made by an organisation fail (Nutt, 1999), whereas nearly 70 percent of strategies and strategic plans and decisions are not implemented successfully according to Okumus, 2003; and Corboy and O'Corrbui, 1999. Moreover, a failure in the implementation of any strategic decision can be very costly, both in terms of design costs and benefits which have already been accrued. To Heracleous (2003) the failure of strategic decision making means that the organisation fails to exploit its resources in a beneficial manner.

It could be argued that the traditional approach in dealing with implementation was to treat it as an activity following decision formulation without taking into consideration the importance of this activity on the success of the whole process of strategic decision making (Bourgeois and Brodwin, 1984). As Heracleous (2003) notes, many decisions have been taken without considering their corresponding implementation procedures which may pose a risk to the organisation and may cause it to lose the resources which it requires to achieve other goals. In other words, companies often fail to operationalise their strategies so as to improve the likelihood of successful implementation. Discovering the reasons why a strategy implementation process is unsuccessful is, nevertheless, a challenging task. Sterling (2003) commented that many of the most commonly cited causes for implementation failure are either myths or excuses that have gained credibility from being repeated often.

One of the reasons for this failure to implement strategies is the fact that managers try to implement them without a careful understanding of the factors which are important in helping to make implementation work (Okumus, 2003). Accordingly, managers have to be aware of the importance of strategic decisions as well as of the successful implementation of these decisions and their effect on the success of their organisation. Nevertheless, in spite of the above discussion, organisations are still focusing on the first step; that of decision making without paying sufficient attention to the implementation stage. According to Grundy (1998) companies have to move away from a 90:10 attention distribution in favour of strategy formulation compared to its implementation to a 50:50 distribution which is concerned equally with both the formulation and implementation stages.

Recent studies in the strategic management field indicate a lack of knowledge concerning strategy implementation (Miller et al., 2004; Hickson et al., 2003; Aaltonen and Ikavalko, 2002; Okumus, 2001; Miller, 1997; Judge and Stahl, 1995; Kargar and Blumenthal, 1994; 
Alexander, 1985). This finding was also supported by Minarro-Viseras et al. (2005) who commented that:

"The issue of implementation has received less attention, although implementation of strategic initiatives has frequently been considered to be the graveyard of strategy" (p. 151).

Notwithstanding, most strategic decision literature merely focuses on how to make and develop strategies rather than on how to implement them (Nutt, 1998; Skivington and Daft, 1991; Alexander, 1985). Furthermore, the literature that does deal with the implementation stage was carried out primarily in the USA and Europe. For this, Okumus (2003) suggested that studying the implementation process within companies in other countries and cultures would add a new insight on strategic management.

Studies have shown that despite the heterogeneity of organisational cultures within one country, they themselves are affected by the national culture (Soeters and Schreuder, 1988; Hofstede et al, 1990 in Parboteeah et al. 2005). This was supported by Dedoussis (2004) who claimed that:

“...since an organisation is a social system operating within the context of a particular society, it cannot be totally immune from broader socio-cultural forces. The impact of these forces extends not only to the "soft stuff", that is the way members of the organisation relate to each other that even culture-free proponents are prepared to accept, but its way also extend to the "hard stuff", that is systems, structure, and process as these are decided and set in place by human beings." (p. 20)

Several models of national culture have been suggested (see Parsons and Shils, 1951; Kluckhohn and Strodtbeck, 1961; McClelland, 1961). Models such as Hall's (1976), Laurent's (1983, 1986), and Trompenaars's (1994) have been widely debated and replicated and are considered to be some of the best-known models that investigate the effect of culture in business and economic studies. Nevertheless, one of the most useful and indeed most frequently used models of the possible effect of national culture on the management practices is the one suggested by Hofstede (1980, 1991, and 2001). Many researchers agreed on the validity of using this model to describe workplace behaviour (see Chiang, 2005; Pagell et al., 2005; Merritt, 2000; Chapman, 1997).

Hofstede developed four dimensions to describe the differences among nations. These dimensions are classified as power distance, uncertainty avoidance, individualism collectivism, and masculinity - femininity. In his study carried out in 1993, Hofstede added a fifth dimension - future orientation - in order to cover one criticism of his study of not capturing all potential dimensions of culture (Cavusgil et al., 2008). Arab countries were not included in Hofstede's fifth dimension; consequently, this study will use only the first four dimensions to explain the possible effect of culture on the implementation process of strategic decisions within banks in Jordan. Table (1) shows Hofstede's initial four dimensions and the findings for the Arab countries in accordance with his model as the frame of reference. 
Table 1. Hofstede's five dimensions and his description for the Arab countries

\begin{tabular}{|l|l|}
\hline \multicolumn{1}{|c|}{ Hofstede's Dimensions } & \multicolumn{1}{c|}{ Description } \\
\hline Power Distance & Large power Distance \\
\hline Uncertainty Avoidance & Moderate Uncertainty Avoidance \\
\hline Individualism-Collectivism & Collectivism \\
\hline Masculinity-Femininity & $\begin{array}{l}\text { Masculinity-Femininity (with being relatively closer to } \\
\text { being feminine than masculine) }\end{array}$ \\
\hline
\end{tabular}

Jordan is centrally located in the Middle East, and it lies at the eastern end of the Mediterranean Sea. Jordan borders in the north on Syria, in the east on Iraq and Saudi Arabia, in the south on Saudi Arabia, and in the west across the Jordan River on Israel and the Palestine National Authority. Recent evidence shows that the continuing Arab-Israeli conflict and the Gulf war create a wide range of economic problems in the Middle East and have had a huge impact on the economy, thus Jordan is vulnerable to external shocks and regional unrest, a situation which is aggravated by its limited natural resources. The 1994 peace treaty between Israel and Jordan (Wadi Araba Treaty) resulted in a relatively active economy, but at the same time led to a higher rate of inflation (Lorch, 2007). A more recent example of the impact of the Arab-Israeli conflict is how the events that took place in Lebanon related to the Israeli strikes on its lands have led to the postponing or cancelling of a number of plans for several banks in Jordan, hence negatively affecting their performance, including one of the banks in the sample of this study.

Compared to other Middle Eastern countries, Jordan has a stable political environment and is considered to be an attractive economical environment for many local and foreign investors (Amman Stock Exchange, 2008). This is shown by the steady increase in local investment since 2001 reaching $2.48 \%$ in 2007, whereas foreign investment has increased by $2.57 \%$ for the same year as shown in tables 2 and 3 (Jordan Investment Board, 2009). 
Table 2. Jordan Investment Board (1)

New Project Applications for 2001 (Promotional Investment Law)

18th Jan 2001 - 13th Dec 2001

\begin{tabular}{|c|c|c|c|c|c|c|c|c|}
\hline \multicolumn{9}{|c|}{ Investment size (JD) } \\
\hline Sector & Number & Domestic & Arab & $\begin{array}{l}\text { American } \\
\text { and } \\
\text { Canadian }\end{array}$ & European & $\begin{array}{c}\text { Other } \\
\text { countries }\end{array}$ & $\begin{array}{c}\text { Total } \\
\text { (non-Jordanian) }\end{array}$ & Total \\
\hline Manufacturing & 296 & $386,410,967$ & $13,295,000$ & $17,586,880$ & $30,034,312$ & $318,545,000$ & $379,461,192$ & $765,872,159$ \\
\hline Hospitality & 10 & $41,400,068$ & $13,050,000$ & & $6,050,000$ & & $19,100,000$ & $60,500,068$ \\
\hline Agriculture & 24 & $19,452,000$ & $1,770,000$ & 459,000 & & $1,049,000$ & $3,278,000$ & $22,730,000$ \\
\hline Health care & 7 & $24,051,640$ & & 150,000 & $5,000,000$ & & $5,150,000$ & $29,201,640$ \\
\hline $\begin{array}{l}\text { Maritime } \\
\text { and rail } \\
\text { transportation }\end{array}$ & 0 & & & & & & & \\
\hline $\begin{array}{l}\text { Conferences } \\
\text { and } \\
\text { exhibitions. }\end{array}$ & 0 & & & & & & & \\
\hline $\begin{array}{l}\text { Recreations } \\
\text { and theme } \\
\text { parks }\end{array}$ & 2 & 938,000 & & $2,112,000$ & & & $2,112,000$ & $3,050,000$ \\
\hline Utilities & 339 & $472,252,675$ & $28,115,000$ & $20,307,880$ & $41,084,312$ & $319,594,000$ & $409,101,192$ & $881,353,867$ \\
\hline Total & 678 & 944505350 & 56230000 & 40615760 & 82168624 & 639188000 & 818202384 & 1762707734 \\
\hline
\end{tabular}

Furthermore, the banking industry is one of the most important industries in the Jordanian economy (Amman Stock Exchange, 2008). For the aforementioned reasons, many foreign banks are trying to invest in Jordan and to open new branches in order to expand their operation in the area which increases the degree of competitiveness within this industry. For example, three international banks started operating in Jordan in 2004. Those banks are Audi bank, National Bank of Kuwait, and Blom bank (http://www.cbj.gov.jo). 
Table 3. Jordan Investment Board (2)

New Project Applications for 2007 (Promotional Investment Law)

9th Jan 2007 - 13th Dec 2007

Investment size (JD)

\begin{tabular}{|c|c|c|c|c|c|c|c|c|}
\hline Sector & Number & Domestic & Arab & $\begin{array}{l}\text { American } \\
\text { and } \\
\text { Canadian }\end{array}$ & European & $\begin{array}{c}\text { Other } \\
\text { countries }\end{array}$ & $\begin{array}{c}\text { Total } \\
\text { (non-Jordanian) }\end{array}$ & Total \\
\hline Manufacturing & 380 & $976,622,534$ & $279,991,127$ & $89,520,960$ & $38,196,000$ & $377,312,930$ & $785,021,017$ & $1,761,643,452$ \\
\hline Hospitality & 13 & $147,752,815$ & $259,094,840$ & & & & $259,094,840$ & $406,847,655$ \\
\hline Agriculture & 19 & $13,110,970$ & $2,550,000$ & & & $1,500,000$ & $4,050,000$ & $17,160,970$ \\
\hline Health care & 6 & $26,833,200$ & & & $1,500,000$ & & $1,500,000$ & $28,333,200$ \\
\hline $\begin{array}{l}\text { Maritime } \\
\text { and rail } \\
\text { transportation }\end{array}$ & 0 & & & & & & & \\
\hline $\begin{array}{l}\text { Conferences } \\
\text { and } \\
\text { exhibitions }\end{array}$ & 2 & $6,990,351$ & & & & & & $6,990,351$ \\
\hline $\begin{array}{l}\text { Recreations } \\
\text { and theme } \\
\text { parks }\end{array}$ & 1 & 200,000 & & & & & & 200,000 \\
\hline Utilities & 0 & & & & & & & \\
\hline Total & 421 & $1,171,509,870$ & $541,635,967$ & $89,520,960$ & $39,696,000$ & $378,812,930$ & $1,049,665,857$ & $2,221,175,628$ \\
\hline
\end{tabular}

Previous studies came out with many factors that might affect the implementation process of strategic decision (See for example Miller et al., 2004; Kickson et al., 2003; Al-Ghamdi, 1998). Such factors are the use of a reward system, involvement and participation of employees, communication and the existence of interest groups. This study focuses on the implementation process of strategic decisions within the Jordanian banking sector. More specifically, to achieve the purpose of this study, it was decided that the study should "investigate the nature of the implementation process within the three banks -mentioned earlier - in terms of four main issues: the role of external companies, simulation of the implementation process, incremental approach to implementing strategic decisions, and buffering time period tactic". Hofstede's model is used to explain the nature of the implementation process of strategic decisions within banks in Jordan. 


\section{Methodology}

Taking into consideration that this study examines the nature implementation process of strategic decisions within banks in Jordan, an interpretative methodology with an inductive qualitative approach was adopted. Due to the sensitivity of the studied subject, the research faced a problem of gaining access to the banks (Miller, 1990). In order to obtain a clear and complete picture of the implementation of the strategic decisions in as far as possible (Locke and Golden-Biddle, 1997), twelve strategic decisions case studies in three out of the total number of fifteen local banks in Jordan were included in this study. These banks are considered to be the largest banks in Jordan in terms of their market share. Tables 4, 5, and 6 show a summary of those decisions. Furthermore, in addition to the sensitivity of the subject, invasion of privacy was a critical element (Bryman and Bell, 2003) which banks asked about before consenting to participating in this research. The banks agreed to participate in the research as long as their names would be kept confidential. For this reason, the three banks will be referred to as bank Alpha, Beta, and Gamma.

Table 4. The explanation of each strategic decision case study which was investigated in bank Alpha

\begin{tabular}{|c|c|c|c|}
\hline \multicolumn{4}{|c|}{ Bank Alpha } \\
\hline Case Study & $\begin{array}{l}\text { Strategic } \\
\text { Decision }\end{array}$ & Objectives & Implementation \\
\hline Centralization & $\begin{array}{l}\text { For all the decisions } \\
\text { to be made in the } \\
\text { central office. } \\
\text { Branches are only } \\
\text { responsible for } \\
\text { providing services. }\end{array}$ & $\begin{array}{l}\text { Increase: the quality of } \\
\text { services provided to } \\
\text { customers in the branches, } \\
\text { the quality of decisions } \\
\text { made inside the bank, the } \\
\text { process of controlling bank } \\
\text { activities, the customers' } \\
\text { base - consequently the } \\
\text { market share, and the } \\
\text { profit of the bank. Unify } \\
\text { banks procedures and } \\
\text { services. }\end{array}$ & $\begin{array}{l}\text { An external consultation company was responsible } \\
\text { for the formulation and the implementation processes. } \\
\text { Meetings were held with the area managers to tell } \\
\text { them about the strategy. Those who were responsible } \\
\text { for the implementation process of this strategy were } \\
\text { provided with the necessary job description to help } \\
\text { them in carrying out the implementation process. } \\
\text { Some training courses were given on how to use the } \\
\text { necessary technology to carry out this strategy. }\end{array}$ \\
\hline Downsizing & $\begin{array}{l}\text { Decreasing the } \\
\text { number of employees } \\
\text { of the bank. }\end{array}$ & $\begin{array}{l}\text { Increase the productivity } \\
\text { of the employees and } \\
\text { consequently the } \\
\text { productivity of the bank. } \\
\text { Reduce the expenses } \\
\text { inside the bank. }\end{array}$ & $\begin{array}{l}\text { Implement this strategy by offering some of the } \\
\text { leaving employees' compensation to for voluntary } \\
\text { resignation. }\end{array}$ \\
\hline Lottery & Introducing special & Increase the liquidity & Training staff in branches on how to use the system \\
\hline
\end{tabular}




\begin{tabular}{|c|c|c|c|}
\hline & $\begin{array}{l}\text { certificates to } \\
\text { customers to allow } \\
\text { them to win financial } \\
\text { prizes. }\end{array}$ & $\begin{array}{l}\text { inside the bank and the } \\
\text { number of customers } \\
\text { inside the bank and } \\
\text { consequently its market } \\
\text { share. }\end{array}$ & to issue the required certificates. \\
\hline $\begin{array}{l}\text { Business } \\
\text { Intelligence }\end{array}$ & $\begin{array}{l}\text { Establishment of a } \\
\text { data base for Business } \\
\text { Units to be used for } \\
\text { making decisions. }\end{array}$ & $\begin{array}{l}\text { Increase the speed of } \\
\text { making decisions and the } \\
\text { quality and the accuracy of } \\
\text { the information used in } \\
\text { decision making. }\end{array}$ & $\begin{array}{l}\text { The Finance and the IT departments decided on } \\
\text { which system to implement. The external company } \\
\text { worked together with the finance department to } \\
\text { implement this system. Training staff in the head } \\
\text { quarter on how to use the new system. }\end{array}$ \\
\hline Re-positioning & $\begin{array}{l}\text { Changing the brand } \\
\text { image of the bank in } \\
\text { its customers' mind }\end{array}$ & $\begin{array}{l}\text { Improve the way } \\
\text { customers look at the } \\
\text { bank. Increase customers' } \\
\text { base, market share, and } \\
\text { consequently the profit of } \\
\text { the bank. }\end{array}$ & $\begin{array}{l}\text { Ask an external company to design the new brand. } \\
\text { The marketing department was responsible for the } \\
\text { implementation process. }\end{array}$ \\
\hline Auditing & $\begin{array}{l}\text { Using IT to encourage } \\
\text { bank employees in } \\
\text { branches to share } \\
\text { information and } \\
\text { experiences with the } \\
\text { purpose of improving } \\
\text { their work and } \\
\text { decreasing the risk } \\
\text { associated with it. }\end{array}$ & $\begin{array}{l}\text { Encouraging employees to } \\
\text { participate in the process } \\
\text { of improving the work } \\
\text { within their departments } \\
\text { and consequently improve } \\
\text { the quality of work inside } \\
\text { the bank. Reduce the effect } \\
\text { of any unexpected events } \\
\text { with the aid of clear } \\
\text { procedures of how to carry } \\
\text { out work inside the bank. } \\
\text { This strategy adds value to } \\
\text { the bank and helps it to } \\
\text { achieve its goals and } \\
\text { objectives with minimum } \\
\text { risk. }\end{array}$ & $\begin{array}{l}\text { Groups from the Auditing department were sent to } \\
\text { branches to explain the system and how to use it to } \\
\text { their employees. Employees in braches contacted the } \\
\text { IT and the Auditing departments regarding any } \\
\text { problem. }\end{array}$ \\
\hline
\end{tabular}

Triangulation was used in order to decrease the bias associated with the use of a single data collection method (Bryman, 2004; Hussey and Hussey, 1997). Direct interaction with the informants inside the bank through interviews was conducted to facilitate the collection of data that were used to gain a better understanding of the issue of implementation of strategic 
decisions. Observation was used as second method to collect data by observing how employees interact and behave within the three banks. Additionally, using this method of data collection, the researchers observed the implementation activities at the different banks which gave them the chance to not only learn about the implementation but to 'feel it' (Gill and Johnson, 1997). Finally, documents related to strategic decisions case studies, although only limited access to documents was allowed by the banks, were used, as a third method to collect data, to solve some of the difficulties which were faced during the interviews (following Cray et al., 1988, 1991) and to follow up on some of the issues that emerged during the interviews.

Table 5. The explanation of each strategic decision case study which was investigated in bank Beta

\begin{tabular}{|c|c|c|c|}
\hline \multicolumn{4}{|c|}{ Bank Beta } \\
\hline Case Study & Strategic Decision & Objectives & Implementation \\
\hline Centralization & $\begin{array}{l}\text { All the decisions are made in the } \\
\text { central office. More specialised } \\
\text { teams in the centres to deal with } \\
\text { any decision concerning both } \\
\text { the product and the service } \\
\text { provided to customers. Branches } \\
\text { are only responsible for } \\
\text { providing services. }\end{array}$ & $\begin{array}{l}\text { To reach a consensus on decisions } \\
\text { inside the whole bank. Reduce the } \\
\text { costs inside branches. Increase the } \\
\text { quality of service provided to } \\
\text { customers and the bank's profitability } \\
\text { and market share. }\end{array}$ & $\begin{array}{l}\text { An external consultation company was } \\
\text { responsible for the formulation and the } \\
\text { implementation processes. Meetings were held } \\
\text { with the branches' managers to tell them about } \\
\text { the strategy. Those who were responsible for } \\
\text { the implementation process of this strategy } \\
\text { were provided with the necessary job } \\
\text { description to help them in carrying out the } \\
\text { implementation process. Some training courses } \\
\text { were given on how to use the necessary } \\
\text { technology to help them carry out their jobs. }\end{array}$ \\
\hline Downsizing & $\begin{array}{l}\text { Reducing the number of } \\
\text { employees inside the bank. }\end{array}$ & $\begin{array}{l}\text { Increase the productivity of the } \\
\text { employees and the efficiency of the } \\
\text { bank. Speeding up the decision } \\
\text { making process. Decrease the } \\
\text { expenses inside the bank. }\end{array}$ & $\begin{array}{l}\text { Meeting with those who were asked to leave the } \\
\text { company. Offer them a compensation to resign } \\
\text { voluntarily or giving rewards to those who are } \\
\text { still working inside the bank to motivate them } \\
\text { to work hard. }\end{array}$ \\
\hline New System & $\begin{array}{l}\text { Both IT hardware and software } \\
\text { have been updated within the } \\
\text { bank. }\end{array}$ & $\begin{array}{l}\text { Increase the efficiency of the } \\
\text { operations inside the bank, the quality } \\
\text { of decision making inside the bank } \\
\text { and the quality of the services } \\
\text { provided to the bank's customers. }\end{array}$ & $\begin{array}{l}\text { The bank had some goals and objectives. A } \\
\text { foreign company provided them with the new } \\
\text { system. The bank and the company worked } \\
\text { together to implement this system inside the } \\
\text { bank. Training courses were provided for staff } \\
\text { on how to use the new system. }\end{array}$ \\
\hline
\end{tabular}

Fifty-eight interviews with both decision makers and implementers were carried out distributed across the three banks. The minimum time of an interview was half an hour and the maximum time was an hour and a half. Following Nutt's (2000) approach "the 
interviewer first determined the nature of the decision that was made and then looked for what shaped the decision" (Nutt, 2000, p. 89). The first interview with the primary informants - decision makers - was inductive. It aimed to elicit their view of implementation to give the researchers a good understanding of the strategic decision being studied.

Table 6. The explanation of each strategic decision case study which was investigated in bank Gamma

\begin{tabular}{|c|c|c|c|}
\hline \multicolumn{4}{|c|}{ Bank Gamma } \\
\hline Case Study & Strategic Decision & Objectives & Implementation \\
\hline Restructuring & $\begin{array}{l}\text { Changing the operations } \\
\text { and the structure of the } \\
\text { organisation. }\end{array}$ & $\begin{array}{l}\text { Eliminate the bureaucracy inside } \\
\text { the bank. Increase the efficiency } \\
\text { and the productivity of the bank. } \\
\text { Decrease the costs and increase } \\
\text { the profit of the bank. }\end{array}$ & $\begin{array}{l}\text { An external consultation company was } \\
\text { responsible for the formulation and the } \\
\text { implementation process. A committee } \\
\text { inside the bank was formed to ensure a } \\
\text { smooth implementation. Many } \\
\text { departments were supposed to merge. The } \\
\text { span of control was supposed to increase. }\end{array}$ \\
\hline Re-positioning & $\begin{array}{l}\text { Change the image of bank } \\
\text { from its customers' point } \\
\text { of view. }\end{array}$ & $\begin{array}{l}\text { Improve the way customers look } \\
\text { at the bank. Increase the customer } \\
\text { base, market share, and } \\
\text { consequently the profit of the bank }\end{array}$ & $\begin{array}{l}\text { An external consultation company was } \\
\text { responsible for the formulation and the } \\
\text { implementation process. Changing the lay } \\
\text { out of the bank. Advertising the new image } \\
\text { in the media. }\end{array}$ \\
\hline Segmentation & $\begin{array}{l}\text { Segmentation of the } \\
\text { bank's customer accounts. }\end{array}$ & $\begin{array}{l}\text { Improve the level of services } \\
\text { provided for each segment. Attract } \\
\text { more customers to use the banks' } \\
\text { services. Increase the market share } \\
\text { and the profitability of the bank. }\end{array}$ & $\begin{array}{l}\text { Carefully studying the bank's customers' } \\
\text { accounts. Dividing them into different } \\
\text { segments. Training courses were provided } \\
\text { to staff to help them in serving customers } \\
\text { effectively. }\end{array}$ \\
\hline
\end{tabular}

The decision maker was asked to inform the researchers about the employees who were responsible for the implementation process. The researchers asked every decision maker to contact those who were involved with implementation. This showed them that this research is supported by top management, which guaranteed access to more valuable information regarding the strategic decision under study. This technique, which is called "snowball sampling", was used in the prior studies by numerous researchers who investigated the implementation of strategic decisions (Miller et al., 2004; Hickson, et al., 2003; Nutt, 2002, 2000, 1998). Snowball sampling "consists of identifying respondents who are then used to refer researchers on to other respondents" (Atkinson and Flint, 2001, p. 1). It includes asking the subject or the informant to refer the researchers to another subject who will be asked to give the name of another subject and so on. It is mainly used in studies with a qualitative, exploratory, and descriptive nature such as this research (Hendricks et al., 1992). However, 
the use of this technique is considered to be a limitation in this study. The managers could refer the researchers to only those employees whom they could expect to give the same answers as their superiors had given previously. Nevertheless, the researchers tried to overcome this limitation by using observation and documentation to supplement the data collected for this study (triangulation).

The researchers encouraged the respondents to cooperate by for instance telling them how long the interviews would last as well as by ensuring them anonymity and confidentiality (Dean and Whyte, 1978). The interviews were conducted at the interviewees' workplace and at a time of their convenience during the working day and in their offices. Taking into consideration that the informants were the managers and/or decision makers and implementers, and the fact of them being engaged in many tasks and responsibilities, some of the scheduled interviews were either cancelled or re-scheduled. This shows the researchers flexibility through leaving the freedom to the selected managers to specify the most suitable time for them to be interviewed. Three interviews were conducted with decision makers who had already retired from their banks. Those informants were contacted by the researchers who asked for their permission to be interviewed. Those interviews were conducted in these decision makers' homes and according to their convenience.

The researchers depended on the questions which were formulated and asked in the previous studies to form the questions of the semi-structured interviews of this study (see Alexander, 1985; Miller, 1990; Pinto and Prescott, 1990; Rodrigues and Hickson, 1995; Miller, 1997; Al-Ghamdi, 1998; Noble and Mokwa, 1999; Hickson et al., 2003; Miller et al., 2004). The interview questions were translated into Arabic by the researchers (this language being the mother tongue of two of the researchers) and were reviewed by a team of external judges. Agreeing with Balbinotti et al. (2006) an approach which eliminates individual bias and increases the objective comparison between both the questions in English and in Arabic was adopted. A copy of the questions in English was given to each of the four reviewers to translate into Arabic. A meeting was held after this where the researchers together with the four other people discussed the translation in order to combine the five Arabic copies into one single copy. An acceptable level of agreement was found in the different translations and any disagreements were solved after a thorough discussion. The final version was given to another person who is studying Arabic - English translation for revision. Based on his comments, the questions in Arabic were redesigned for the last time and the pilot study was started shortly after.

Every interview began by asking the informants to tell a narrative story about strategic decisions and their implementation. This was followed by open-ended questions about specific issues about that decision and its implementation. As Hakim (1992) and Potter and Wetherell (1987) commented, when narrative is combined with semi-structured interviews, it is more akin to in-depth conversations than to sessions of solely questions and answers. All the interviews were transcribed as soon as possible. Each interview was transcribed into Arabic and then translated into English. This was a time consuming process but it was 
important as it minimized the level of power of the researchers over the informants and thus strengthened the validity of the interview. The validity was further strengthened by sending each informant a copy of each transcript to ensure that what was written in the transcript was what the informant had meant to say (Nutt, 1998; 2002). The interview was supported by looking at the related documents inside the bank in order to make sure that there was no gap between what had been said and what was written in the interview. The researchers faced one incident where there was a difference between what was said by one informant and what was written in the documents. Following Nutt's suggestion (1998), such inconsistencies and gaps between the two were solved by a follow-up interview with the primary informant who first suggested the strategic decision.

The process of analyzing data was started shortly after the data collection stage. Data were analyzed on a content level through importing them into QSR NVivo. All the data obtained from the interviews and the notes which were taken through the observation and the documentation methods were saved as RTFs36 and then imported into NVivo37.

The coding process, which involved organizing the data of each strategic decision case study into cases in the node area, began after the researcher had read the transcription of the interviews as well as the notes from the observation and the documentation several times. Consequently, a framework of nodes38, which involves the different themes of this research, was established which represents the understanding of these documents (Mitchell and Kristovics, 2005). Furthermore, using NVivo helped to retrieve those memos more quickly and to facilitate the iterations within data coding and analysis (Siwale, 2006).

\section{Discussion}

As mentioned before, interviews, observation, and documentation were used to the collect the data of this study. The empirical data regarding the nature of the implementation process with the three banks will be discusses in terms of four main elements: the role of external companies, simulation of the implementation process, using an incremental approach, and applying a buffering time period tactic to implement these decisions. The use of a simulation technique and applying a buffering time period tactic are new to the implementation studies and were not discussed before. However, the use of external companies and the buffering time period were mentioned by Okumus (2001) and Raps (2003) respectively but they dealt with them as factors which affect the implementation process not as elements which explain the nature of the process itself. Furthermore, the incremental approach was discussed in prior work by Braybrooke and Lindblom, (1963) nevertheless; they discussed its effect on the actual making of the decision rather than the implementation process.

\section{The Role of External Companies}

The role of external companies has been mostly overlooked in previous studies except for Okumus's 2001 study. Okumus recognised this element as a factor which affects the successful implementation of strategic decisions. He called them external partners and identified them as those who provide knowledge to an organisation. However, their role and their effect on the outcome of the implementation process were not discussed in depth. 
The data of this study show that all three banks used an external company to plan for and implement most of their strategic decisions. The data also show that external companies played an important role in the outcome of the implementation of strategic decisions within those banks. Moreover, this impact can be seen from the early stages of the strategic decision making processes and not just in the implementation process.

For example, Bank Alpha asked an external company to come up with some strategies in order to improve its competitive position in the banking industry. The recommendation was to change the way in which the bank operates and deals with its customers. Many strategic decisions were suggested including centralization, downsizing, Business Intelligence, and repositioning strategies. The researchers asked for this company's name, but for confidentiality reasons, its name was kept a secret by the decision makers.

Generally speaking, the role of the external company was to study the position of a bank and the industry surrounding it. This company then provided that bank with strategies on how to improve its position within the industry. Next a committee was formed which involved employees from the bank and representatives from the external company. This committee was responsible for studying the external company's suggestions and providing the board of directors with its recommendations. The data of this study collected through interviews, documentation, and the researchers' observation indicate that the role of the external company did not stop at the planning stages of a strategic decision but was also extended to the implementation of that decision.

The data show that the external company had a positive impact on the implementation process of few strategic decisions. However, their role negatively affected the way of the implementation of some others. The latter was obvious in the Treasurer and the downsizing strategies in bank Alpha, the downsizing strategy in bank Beta, and the restructuring, re-positioning, and the segmentation strategies in bank Gamma. Many informants agreed on the fact that their hiring a foreign company to plan and implement their strategies had been a mistake. For example, a manager in Bank Alpha while discussing the downsizing strategies stated that:

"The culture in this bank used to be a job for life. When I joined they told me congratulations you have got a job for life. Four years later they started cutting jobs. They used a foreign company which operates in a Western country. This company applied things without knowing anything about how things are done here. Many people were against this strategy and against what this company is doing."

A consultant in bank Gamma whom the researchers interviewed agreed with the above comments. While discussing the restructuring strategy, this consultant stated that the ideas which had been brought by the external company were ideal to be implemented in the country where his company operates, but not in Jordan. He added that it was a mistake on behalf of the company to try to implement those ideas without adopting them to fit in with the beliefs of people in Jordan. He commented: 
"The fact of introducing the best practice from another part of the world into Jordan was wrong. It is a big hurdle to jump. Does it make sense? In other words, the banks practices that exist are quite dated (old fashioned) and therefore they try to bring the best practices in the world. There is a long, long curve in order to get from where the bank is to where it has to be. And perhaps we underestimated the amount of the gap that exists between the best practice and the actual situation in the bank. I think that this is a fair assumption to make."

The results of this factor are in line with the findings of prior research. For example, using a 'Western' company to plan and implement strategic decisions within the three banks reflect Dadfar's (1984, 1987, and 1990) result of Arabs caring a lot about their social prestige and consequently choosing large organisations as their partners. Furthermore, in his study carried out in 1991, Hofstede questioned the applicability of Western theories to other places, an argument which is confirmed by our data. Moreover, these results corroborate those of Ali (1990, 1993, and 1995) and Sabri (1997) who commented that managerial practices within an organisation are culturally dependent and that what works in one country might not work in another. They commented that implementing Western theories without adopting them to Arab culture would cause critical managerial problems.

\section{Simulation of the Implementation Process}

A new idea which was presented by the managers and which was not discussed in the previous studies is the use of simulation techniques before starting to fully implement certain strategic decisions. Simulation can be defined as "an attempt to solve a problem or work out the consequences of doing something by representing the problem or possible course of events" (Collins Dictionary). The purpose of applying this technique is to discover any deficiencies concerning a targeted strategy before its actual implementation.

For example, bank Beta used this technique to try the new system strategy before actually implementing it. Artificial accounts were created for the new system and the research and development department tested the efficiency and the applicability of the new system. After testing the new system and dealing with any problems, this system was installed in small bank branches where the bank could test the system in a real life situation and where they could easily control any mistakes. After ensuring that the new system worked efficiently, it was implemented in all the bank's branches. One informant in Bank Beta commented that:

"The implementation process was 100\% controlled to make sure that there were no mistakes. You are talking here about customers' accounts with lots of money associated with them and any mistake would affect the reputation of the bank. We first tried it on artificial accounts, and then moved to implementing it in the smaller branches. After making sure that things were working well, we moved onto the bigger branches and so on so forth."

The nature of the financial operations inside banks as well as some strategies applied to these operations force banks to ensure minimal mistakes are associated with these strategies. This technique was only used with strategic decisions which were characterised as being complex and with those which directly affected all the operations within the bank. These strategic decisions were the centralization and the Business Intelligence strategies in bank Alpha as 
well the centralization and the new system strategies in bank Beta. The empirical data of this study show that the use of this technique helped better implementing strategic decisions by discovering the potential problems before actually implementing a strategic decision.

The same to the incremental approach which will be discussed later, the use of a simulation technique before actually implementing a strategic decision within banks in Jordan might be explained by some characteristics of Arab culture. According to Hofstede, Arab culture is characterized by having high uncertainty avoidance. For this, banks in Jordan apply the simulation technique in order to reduce the ambiguities associated with implementing a strategic decision and to increase the probability of its success.

\section{Incremental Approach to Implementing Strategic Decisions}

Although this approach has been discussed in the previous studies, this study is considered to be one of the first studies which discuss the effect of the incremental approach on the way in which strategic decisions are implemented. It is almost impossible to reach consensus on organisational goals and objectives (Lindblom, 1959). According to this approach, goals and values of a strategic decision are fragmented. Consequently, the managers should adopt a strategy of incrementalism through which small changes can be evaluated and achieved (Lindblom, 1959). The incremental approach was only discussed by the previous studies in terms of decision-making rather than implementation (See Braybrooke and Lindblom, 1963). Although Braybrooke and Lindblom (1963) commented that one must be aware of what happens after the decisions have been made, they did not test the effect of this process on the implementation stage of the decision making process. Nevertheless, they suggested that the implementation process would be easier when incremental approach is adopted (Miller, 1990).

Taking into consideration that this study focuses on the implementation of strategic decisions, the researchers did not investigate whether or not banks in Jordan applied the incremental approach while making their decisions. The information deducted from interviews, documents, and observation showed that the incremental approach was adopted in the implementation stage by all three banks. According to all the informants, banks in Jordan divided the implementation process of most of their strategic decisions, except for two, into several stages. Those two strategic decisions were the Lottery and auditing strategies in bank Alpha. According to the informants interviewed, those strategies were implemented in their totality and only one stage was required to implement them. For the remaining strategies, goals were set and objectives were identified for every stage. These goals and objectives were measured at the end of every stage to ensure that the implementation process was carried out according to plan, accordingly, eliminating or reducing the negative effect of any problem associated with the implementation process. A decision maker in bank Alpha, while discussing the Business Intelligence strategy, commented that:

"Bank Alpha is one of the biggest banks in Jordan and it wouldn't risk any strategy by not having a measurement to make sure that it would be successfully implemented. There was some form of measurement to control the whole implementation process. The bank defined some goals for each stage and every stage had to meet its goals and objectives." 
As mentioned previously, the decision to apply the simulation technique and the incremental approach within the three banks in Jordan might be explained by the high uncertainty avoidance which characterises Arab culture and consequently Arab organisations. Arab culture is characterised by having high uncertainty avoidance and long-term planning, and hence, managers have to make sure that all strategic decisions are controlled to guarantee their future success. Control comes in many forms. The decision to apply the simulation technique and the incremental approach within the three banks in Jordan are examples of some techniques used to reduce the number of errors and to reduce the risk associated with the decisions they make, consequently, to increase the probability of achieving the goals and objectives of a decision. As mentioned earlier, the idea of the incremental approach is to reduce the effect of uncertainty associated with implementing strategies by dividing the implementation process into smaller parts so as to ensure that each part can be controlled and checked to be working as planned.

\section{Buffering Time Period Tactic to Implement Strategic Decisions}

With the exception of Raps' study carried out in 2005, this factor has not been mentioned in most of the implementation studies. However, the data collected through the interviews and the documents show that the three banks in Jordan applied this tactic while implementing most of their strategic decisions.

Taking into consideration that it is difficult to calculate an appropriate time frame, Raps (2005) considered buffer time as a technique which decision makers have to be aware of when calculating the expected time to implement a strategic decision. According to these researchers, the time frame should have an extra buffer to allow employees to deal with any unexpected incidents that might occur at any time during the implementation process.

The results of this study agree with what has been discussed by Raps (2005). Similar to the previous two factors, both the high uncertainty avoidance which characterises Jordanian culture and the high environmental uncertainty which describes the Jordanian business climate, play a significant role in the decision to apply this strategy within banks in Jordan. According to many managers, as was the case with the previous two techniques, this tactic was used to reduce the risk associated with any potential problem while implementing their strategic decisions.

The use of this tactic is related to the complexities associated with the implementation of a strategic decision. For example, this tactic was not applied in bank Alpha while implementing the Treasurer and Auditing strategies. The data show that both strategies were easy to implement within bank Alpha. On the other hand, the data show that the other remaining strategies in the three banks were not easy to implement, consequently, the buffering time period tactic was followed to reduce the uncertainties associated with them.

\section{Conclusions and Summary}

Taking into consideration that most of the previous studies were carried out in the USA or Anglo-Saxon countries, and the need for new implementation studies to be carried outside 
those countries (Okumus, 2003), this study investigates the nature of the implementation process of strategic decisions within the banking industry in Jordan.

This study concludes that the three banks studied in Jordan followed a similar approach to implement most of their strategic decisions. It was the case in all three banks that an external Western company was asked to develop a strategic decision in order to help the bank to increase its performance. This external company was also involved in the implementation process of any suggested strategic decision. The suggested strategic decision was firstly implemented in an artificial environment, which simulates the actual environment in and outside the bank. After completion of the simulation process and once confident that this stage worked well, the implementation process was then divided into smaller aspects in order to allow for better control over the implementation process. An extra buffering time was then assigned to each strategic decision to reduce the pressure of having a limited time for implementing a strategic decision.

The use of external companies from the West to develop and implement strategic decisions within banks in Jordan was viewed as a managerial problem (Sabri (1997); Hofstede, 1991). The core of this problem is trying to apply Western managerial theories to companies in the Arab world, where Jordan is located, without adapting them to fit in with Arab culture. On the other hand, the use of the simulation technique, incremental approach, and buffering time period played a significant positive role in the implementation of their strategic decisions. The only two factors discussed in the previous studies were that of bringing in an external company which was only identified by Okumus (2001), whereas, the second factor was the use of buffering time tactic which was only discussed by Raps (2005). However, as mentioned before, Okumus (2001) mentioned the use of an external company as a factor which affects the implementation process without discussing it in-depth. Both Raps (2005) and Okumus (2003) used those two techniques as variables which affected the implementation process, whereas in this study, the buffering time period and the use of an external company were used to explain the nature of this process. Moreover, the results of this study provide two new factors (techniques) used in the implementation process which were not discussed by the previous studies and used them together with the buffering time period and the external company as factors which explain the nature of the implementation process within banks in Jordan.

The use of simulation techniques is one of these new factors which were not discussed in the existing studies. Its aim is to assess the applicability of the strategic decision prior to its actual implementation. The use of this technique positively affected the outcome of the strategic decisions where it was used. Most of the previous studies discussed the incremental approach and its effect on the making of decisions and predicted its positive effect on the implementation process without actually testing it (see Braybrooke and Lindblom, 1963). The idea behind using this approach was to divide the implementation process into small stages. As mentioned previously, the purpose of this division is to facilitate the control of the implementation process and to reduce the negative effect of any problems associated through early detection. The results show that this technique was successful in achieving its goals and objectives. For example, applying the new system strategy in some small branches in bank 
Beta before fully applying it in all the banks' branches, allowed the bank to overcome any associated problem with implementing the system before they became too large to handle.

The aim of using a buffering time period technique was to give the implementation process extra time in which to solve any problems. Moreover, using the simulation technique, incremental approach, and buffering time period technique to implement strategic decisions within the three banks reflects the effect of the Jordanian culture on the nature of the implementation process. Jordan is located in a very turbulent political area. The Iraq war combined with the Israel-Palestine conflict seriously affects the surrounding environment and causes the banking industry's environment to be characterised by high uncertainty. That is, Arab culture is characterised as having high uncertainty avoidance (Hofstede, 1991). Organisations have to exert extra effort to reduce the negative effect of the surrounding environment. Consequently, the purpose of applying these three techniques while implementing strategic decisions within the banks in Jordan was to reduce the effect of potential problems associated with the implementation process. Furthermore, this was done to reduce the ambiguity of both the environments within and outside the banks.

\section{Limitations, implications, and future recommendations}

The aim of this study is to investigate the nature of the implementation process of strategic decisions within banks in Jordan. Qualitative methods were used to collect the data of this research. Such methods were semi-structured interviews, observations, and documentation. However, some researchers would argue that the results of this study would be strengthened by using questionnaires as a support to the interviews. This was the plan at the beginning; however, the 'time limitations' of this study was the reason why only three techniques were adopted to collect its data. Nevertheless, future research could adopt questionnaires in addition to interviews, documentation, and observations, consequently strengthening the validity and the robustness of their findings by adopting both qualitative and quantitative methods.

Furthermore, the exploratory nature of this research and the use of the case study approach raise the question of the generalisability of its results. This study was applied in three out of fifteen local banks in Jordan. Taking into consideration the similarity of the banks' operations and objectives as well as the fact that they operate in the same cultural environment allows for the possibility that the results of this study can be generalised to other banks in Jordan. However, although the results of this study provide valuable insights into the implementation process, it is preferable not to generalise and for future research to cover more banks in Jordan in order to obtain more robust results concerning this process within the banking industry in Jordan. Moreover, this study being applied to the banking industry in Jordan makes it less relevant to other areas. For example, realizing the different nature of operations within the two industries, the results of this study cannot be generalised to the pharmaceutical industry in Jordan. More research is to be conducted in other industries to investigate whether comparable results concerning the implementation process in other industries could be identified. 
An incremental approach, simulation techniques, and a buffering time period positively helped to implement strategic decisions within banks in Jordan. Managers have to keep using those techniques to implement future strategic decisions. However, they have to reconsider their dependence on foreigner external companies to develop and implement their strategic decisions. The results of this thesis showed that trying to adopt western theories and managerial concepts in Jordanian banks has been unsuccessful. Rather, managers should depend on those companies which are fully knowledgeable of their culture to increase the possibility of successfully implementing their strategic decisions.

Finally, this study is the first study to investigate the implementation process of strategic decisions outside Anglo-Saxon countries. As such, it added a new cultural insight to the implementation literature. However, carrying out the same or similar studies in another country with similar cultural background to Jordan would clarify the effect of culture on the implementation process further. Therefore, more research will be carried out to study organisations in other Arab countries to enlarge the knowledge of such a topic in the future.

\section{References}

Aaltonen, P., \& Ikavalko, H. (2002). Implementing strategies successfully. Integrated Manufacturing Systems, 13(6), 415-418. http://dx.doi.org/10.1108/09576060210436669

Alexander, L. D. (1985). Successfully implementing strategic decisions. Long range Planning, 18(3), 91-97. http://dx.doi.org/10.1016/0024-6301(85)90161-X

Ali, A. (1990). Management theory in a transitional society: The Arab's experience. International Studies of Management and organization, 20(3), 7-35.

Ali, A. (1993). Decision-making style, individualism and attitude toward risk of Arab executives. International Studies of Management and Organization, 23(3), 53-73.

Ali, A. (1995). Cultural discontinuity and Arab management thought. International Studies of Management and Organization, 25(3), 7-30.

Amman Stock Exchange. (2008). Available at: http://www.ase.com.jo/bulletin/yearly/arabic_2007.htm (Retrieved on 14 April 2008)

Al-Ghamdi, S., M. (1998). Obstacles to successful implementation of strategic decisions: The British experience. European Business Review, 98(6), 322-327. http://dx.doi.org/10.1108/09555349810241590

Atkinson, R., \& Flint, J. (2001).Accessing hidden and hard-to-reach populations', Snowball research strategies, Social Research Update 33. University of Surrey, Surrey: Department of Sociology, Balbinotti, M. A. A., Benetti, C., Terra, P. R. S. (2006) 'Translation and validation of the Graham-Harvey survey for the Brazilian context. International Journal of Managerial Finance, 3(1), 26-48.

Bourgeois III, L.J., \& Brodwin, David R. (1984).Strategic implementation: Five approaches to an elusive phenomenon. Strategic Management Journal, 5(3), 241-264. http://dx.doi.org/10.1002/smj.4250050305 
Braybrooke, D., \& Lindblom, C. E. (1963) A strategy of decision. New York: The free press.

Bryman, A., \& Bell, E. (2003). Business research methods. New York: Oxford University Press.

Bryman, A. (2004). Social research methods. 2nd edition. New York: OXFORD University Press.

14- Cavusgil, S. T., Kinght, G., \& Riesenberger, J. R. (2008). International business: Strategy, management, and the new realities. New Jersey: Prentice Hall.

Central Bank of Jordan. (2008). Available at: http://www.cbj.gov.jo/pages.php?menu_id $=12 \&$ local_type $=0 \& l o c a l i i d=0 \& l o c a l \_d e t a i l s=0 \&$ local_details $1=0 \&$ localsite_branchname $=$ CBJ (retrieved on 14 April 2008)

Chapman, M. (1997). Prefaxe: Social anthropology, business studies, and culture issues. International Studies of Management \& Organization, 16(4), 3-29.

Chiang, F. (2005). A critical examination of Hofstede's research and its application to international reward management. International Journal of Human Resource Management, 16(9), 1545-1563,

Corboy, M., \& O'Corrbui, D. (1999). The seven deadly sins of strategy. Management Accounting, 77(10), 29-30.

Cray, D., Mallory, G. R., Butler, R. J., Hickson, D. J., \& Wilson, D. C. (1988). Sporadic, fluid and constricted processes: Three types of strategic decision-making in organizations. Journal of Management Studies, $\quad 25(1), \quad$ 13-40. http://dx.doi.org/10.1111/j.1467-6486.1988.tb00020.x

Cray, D., Mallory, G. R., Butler, R. J., Hickson, D. J., \& Wilson, D. C. (1991). Explaining decision processes. Journal of Management Studies, 28(3), 227-51. http://dx.doi.org/10.1111/j.1467-6486.1991.tb00946.x

Dadfar, H. (1984). Organization as a mirror for reflection of national culture: A study of organizational characteristics in Islamic nations. The 1st International Conference on Organization Symbolism and Corporate Culture. Lund, June, pp. 26-30.

Dadfar, H. (1987). Organization response to a revolutionary environment. Scandinavian Journal of Management Studies, 213-232. http://dx.doi.org/10.1016/0281-7527(87)90006-5

Dadfar, H. (1990). Industrial buying behaviour in the Middle East: a cross-national study. Unpublished $\mathrm{PhD}$ dissertation, Linkoping University.

Dean, J.P., \& Whyte, W.F. (1978). How do you know if the informant is telling the truth? in Bynner, J. and Stribley, K.M. (eds.) (1978), Social research: Principles and procedures. Harlow: Longman Group. 
Dedoussis, E. (2004). A cross-cultural comparison of organizational culture: evidence from universities in the Arab world and Japan. Cross Cultural Management, 11(1), 15-34. http://dx.doi.org/10.1108/13527600410797729

Gill, J., \& Johnson, P. (1997). Research methods for managers. 2nd ed. London: Paul Chapman.

Grundy, T. (1998). Strategy implementation and project management. International Journal of Project Management, 16(1), 43-50. http://dx.doi.org/10.1016/S0263-7863(97)00016-1

Hakim, C. (1992). Research design. London: Routledge.

Hall, E. (1976). Beyond culture. New York: Doubleday.

Harrison, F. E. (1996). A process perspective on strategic decision - making. Management Decisions, 34(1), 46-53. http://dx.doi.org/10.1108/00251749610106972

Hendricks, V. M., Blanken, P., \& Adriaans, N. E. P. (1992). Snowball sampling: A pilot study on cocaine. USA. Rotterdam: IVO, Heracleous, L. (2003), Strategy and organization: realizing strategic management. Cambridge: The Press Syndicate of the University of Cambridge.

Hickson, D. J. Miller, S. J., \& Wilson, D. C. (2003). Planned or prioritized? Two options in managing the implementation of strategic decisions. Journal of Management Studies, 40(7), 1803-1836. http://dx.doi.org/10.1111/1467-6486.00401

Hofstede, G. (1980). Culture's consequences: International differences in work-related values. Beverly Hills, CA: Sage.

Hofstede, G. (1991). Cultures and organizations: Software of the mind. London: McGraw-Hill.

Hofstede, G. (1993). Cultural constrains in management theories. Academy of Management Executive, 7(1), 81-94.

Hofstede, G. (2001). Culture's consequences. Thousand Oaks, CA, Sage,

Hussey, J., \& Hussey, R. (1997). Business research: a practical guide for undergraduate and postgraduate students. Basingstoke: Palgrave.

Jordan Investment Board. (2009). Available at: http://www.jordaninvestment.com/pages.php?menu_id=40\&local_type=0\&local_id=\&local_ details=\&local_details1=\&localsite_branchname=JIB (Retrieved on 3 April 2009)

Judge Jr., William Q., \& Stahl, M. J. (1995). Middle-Manager Effort in Strategy Implementation: a Multinational Perspective. International Business Review, 4(1), 91-111. http://dx.doi.org/10.1016/0969-5931(94)00033-I

Kargar, J., \& Blumenthal, R. A. (1994). Successful implementation of strategic decision in small community banks. Journal of Small Business Management, 32(2), 10-22. 
Kluckhohn, F. R., \& F. L. Strodtbeck. (1961). Variations in value orientations. Evanston, IL: Row, Peterson.

Laurent, A. (1983). The cultural diversity of western concepts of management. International Studies of Management \& Organization, 13(1/2), 75-96.

Laurent, A. (1986). The cross-cultural puzzle of international human resource management. International Studies of Management and Organization, 8(1-2), 75-96.

Locke, K., \& Golden-Biddle, K. (1997). Constructing opportunities for contribution: Structuring intertextual coherence and "problematizing" in organizational studies. Academy of Management Journal, 40(5), 1023-1062. http://dx.doi.org/10.2307/256926

Lorch, N. (2007). The Arab-Israeli Wars', Israeli Ministry of Foreign Affairs. Retrieved on $\begin{array}{lll}3 r d & \text { April } & 2009\end{array}$ (http://www.mfa.gov.il/MFA/History/Modern+History/Centenary+of+Zionism/The+Arab-Isr aeli+Wars.htm)

McClelland, David. (1961). The Achieving Society, D. Van Nostrand, Princeton, NJ.

Merritt, A. (2000). Culture in the cockpit: Do Hofstede's dimensions replicate? Journal of Cross-Culture Psychology, 31(3), 283-301.

Miller, S. (1997). Implementing strategic decisions: Four key success factors. Organization Studies, 18(4), 577-602. http://dx.doi.org/10.1177/017084069701800402

Miller, S. (1990). Successfully implementing strategic decisions: The implementation of top level decisions in organizations. Unpublished PhD research, University of Bradford.

Miller, S., Wilson, D., \& Hickson, D. (2004). Beyond planning, Strategies for successfully implementing strategic decisions. Long range planning, 37(3), 201-218. http://dx.doi.org/10.1016/j.lrp.2004.03.003

Minarro-Viseras, E., Baines, T., \& Sweeney, M. (2005). Key success factors when implementing strategic manufacturing initiatives. International Journal of Operations \& Production Management, 25(2), 151-179. http://dx.doi.org/10.1108/01443570510577010

Mitchell, J., \& Kristovics, A. (2005). Death of an airline: The well-being of Retrenched Ansett staff-Three years on. International Journal of Employment Studies, 13(2), 89-118.

Mockler, R. J. (2001). Making decisions on enterprise-wide strategic alignment in multinational alliances. Management Decision, 39(2), 90-98. http://dx.doi.org/10.1108/EUM0000000005414

Noble, C. H., \& Mokwa, M. P. (1999). Implementing marketing strategies: Developing and testing a managerial theory. Journal of Marketing, 63(4), 57-73. http://dx.doi.org/10.2307/1251974 
Nooraie, M. (2008). Decision magnitude of impact and strategic decision-making process output: The mediating impact of rationality of the decision-making process. Management Decision, 46(4), 640-655. http://dx.doi.org/10.1108/00251740810865102

Nutt, P. C. (1998). Leverage, resistance and the success of implementation. Journal of Management Studies, 35(2), 75-90. http://dx.doi.org/10.1111/1467-6486.00091

Nutt, P. C. (1999). Surprising but true: half the decisions in organizations fail. Academy of management Executive, 1(4), 75-90.

Nutt, P. C. (2000). Decision-making success in public, private, and third sector organizations: Finding sector dependent best practice. Journal of Management Studies, 37(1), 77-108.

Okumus, F. (2001). Towards a strategy implementation framework. International Journal of $\begin{array}{llll}\text { Contemporary Hospitality } \quad \text { Management, } & \text { 327(7), } 338 .\end{array}$ http://dx.doi.org/10.1108/09596110110403712

Okumus, F. (2003). A framework to implement strategies in organizations. Management Decision, 41(9), 871-882. http://dx.doi.org/10.1108/00251740310499555

Pagell, M., Katz, J. P., \& Sheu, C. (2005). The importance of national culture in operations management research. International Journal of Operations \& Production Management, 25(4), 371-394. http://dx.doi.org/10.1108/01443570510585552

Parboteeah, K. P., Cullen, J. B., \& Victor, B., Sakano, T. (2005). National culture and ethical climates: A comparison of U.S. and Japanese accounting firms. Management International Review (MIR), 45(4), 459-481.

Parsons, T., \& Shils, E.A. (Eds.). (1951). Toward a general theory of action, Cambridge, MA: Harvard University Press.

Pinto, J. K., \& Prescott, J. E. (1990). Planning and tactical factors in the project implementation process. Journal of Management Studies, 27(3), 305-327. http://dx.doi.org/10.1111/j.1467-6486.1990.tb00249.x

Potter, J., \& Wetherell, M. (1987). Discourse and social psychology: Beyond attitudes and behaviour. London: Sage.

Raps, A. (2005). Strategy implementation - an insurmountable obstacle? Handbook of Business Strategy, 6(1), 141-146. http://dx.doi.org/10.1108/08944310510557152

Rodrigues, S. B., \& Hickson, D. J. (1995). Success in decision making: Different organizations, different reasons for success. Journal of Management Studies, 32(5), 655-678. http://dx.doi.org/10.1111/j.1467-6486.1995.tb00793.x

Sabri, H. M. (1997). The impact of national culture on organizational structure and culture. Unpublished $\mathrm{PhD}$ research. The University of Leeds. 


\section{Macrothink}

Journal of Management Research

ISSN 1941-899X 2012, Vol. 4, No. 4

Shore, B., \& Cross, B. J. (2005). Exploring the role of national culture in the management of large-scale international science projects. International Journal of Project Management, 23(1), 5-64. http://dx.doi.org/10.1016/j.ijproman.2004.05.009

Siwale, J. N. (2006). The role of loan officers and clients in the diffusion of microfinance: A study of Pride Zambia and Cetzem in Zambia. Unpublished $\mathrm{PhD}$ research. University of Durham.

Skivington, J. K., \& Daft, R. L. (1991). A study of organizational 'framework' and 'process' modalities for the implementation of business-level strategic decisions. Journal of Management Studies, 28(1), 45-68. http://dx.doi.org/10.1111/j.1467-6486.1991.tb00270.x

Soeters, J., \& Schreuder, H. (1988). The interaction between national and organizational cultures in accounting firms. Accounting, Organizations \& Society, 13(1), 75-85. http://dx.doi.org/10.1016/0361-3682(88)90026-8

Sterling, J. (2003). Translating strategy into effective implementation: dispelling the myths and highlighting what works. Strategy \& Leadership, 30(6), 27-34. http://dx.doi.org/10.1108/10878570310472737

Trompenaars, F. (1994). Riding the waves of culture. London: Brealey Publishing.

Wery, R., \& Waco, M. (2004).Why good strategies fail? Handbook of Business Strategy, 5(1), 153-157. http://dx.doi.org/10.1108/10775730410493522 